\title{
THE UNDERGROUND ECONOMY AND FINANCIAL DEVELOPMENT THEORY AND EVIDENCES
}

\author{
Salvatore CAPASSO ${ }^{1}$
}

The underground economy ${ }^{2}$ is a major concern in many economies. In contrast to what might be expected, this is true not only for developing but also for developed countries. Estimates for the former put the size of the underground economy at 30-40\% of GDP, whilst estimates for the latter put the size at 10-15\% of GDP (Schneider, 2007). A large underground sector is not only of economic concern (e.g., due to its potential generate inefficiencies and resource misallocations) but also of political concern (e.g., because of its perception as a measure of a deeply unfair tax system).

Recent years have witnessed a growing body of literature that seeks to understand more fully the characteristics of the shadow economy. Both theoretically and empirically, researchers have sought how best to measure the size of this economy and how best to explain its existence in the first place. The typical focus of attention have been issues such as what motivates firms and individuals not to declare (either fully or partially) their incomes to the government, and what economic and institutional factors might affect this choice.

Answers to these questions may sometimes seem obvious but there is often more than meets the eye. For example, tax evasion is one factor that immediately comes to mind when thinking of an explanation for the underground activity, and some recent evidence lends support for this presumption (e.g., Johnson, Kaufmann and Zoido-Lobatón, 1998a, 1998b; Schneider 1994, 1997; Schneider and Enste, 2000, 2002); yet the data also show that the size of the underground economy differs greatly among regions and economies that display comparable levels of taxation, and that the extent of underground activity is affected little by changes in the fiscal system observations which suggest that there are other key factors at play. The structure of the labor market is certainly among these, since excessive regulations and complicated administrative procedures in the management of human resources can cause firms to divert their operations from the formal to the informal sector (e.g., Johnson, Kaufmann, and Zoido-Lobatón, 1998b).

Evidence does, indeed, seem to suggest that such is the case: according to some estimates, a one point increase in the labour market regulation index is associated to a 10 percent increase in the share of the shadow economy. Other factors that appear to be important include the efficiency of the justice system, the provision of public goods and services, the extent of corruption and the general quality of institutions (e.g., Johnson, Kaufmann and Zoido-Lobatón, 1998a, 1998b; Schneider 2007; Schneider and Enste, 2000, 2002). Again, the way in which such factors can take

\footnotetext{
1 Prof., University of Naples Parthenope, ISMED CNR and CSEF, scapasso@uniparthenope.it

2 Henceforth, we will interchangeably use the terms shadow, informal, hidden or underground economy to designate all of those economic activities, and the income derived thereof, that circumvent or avoid government regulation or taxation.
} 
hold needs careful consideration. For example, corruption may be seen as either a substitute or a complement to underground activity: if bribery acts as a form of taxation, then an increase in bribe demands would be expected to increase this activity (e.g., Hindriks et al., 1999; Johnson, Kaufmann and Zoido-Lobatón, 1998a,b); by contrast, if bribery is a means of by-passing official red-tape, then individuals may be attracted more towards the formal sector (e.g., Choi and Thum, 2004).

In spite of all that has been written on the subject, it is somewhat rare to find discussions of the underground economy that make more than a passing reference to the role of financial markets. Yet there are good reasons to believe why the functioning of these markets may be an important factor in determining underground activity. By affecting access to credit, financial market imperfections - in particular informational asymmetries between borrowers and lenders - can sway firms to operate (either fully or partially) in the informal sector. A firm that chooses to do so will be less able to signal its potential earnings and profitability, and therefore less able to signal its capacity to repay loans. As a consequence, the cost of accessing credit will increase.

Financial intermediaries (including banks) usually adopt standardised procedures for screening borrowers and granting loans. These procedures are based on profitability parameters derived from official balance sheets and income tax documentation. If part of a firm's business is hidden, then it is more difficult to meet intermediaries' requirements and more likely that the cost of credit will be higher. For example, income or goods that are concealed in the informal sector cannot be used as collateral to secure loans for doing business in the formal sector, implying that such loans will be less accessible and/or more costly. A firm will therefore trade off the benefits and costs of concealment in choosing its optimal behaviour. This idea has figured in some recent analyses which demonstrate how a firm's decision to operate in the shadow economy is influenced by its ability to obtain credit, the costs involved in this and the efficiency of financial markets (e.g., Autunes and Cavalcanti, 2007; Norris and Feltenstein, 2005; Straub 2005).

Given the above, it is possible to argue that improvements in the functioning of financial markets - i.e., financial development - are an important means of curbing underground economic activity. Such improvements may take a variety of forms, not least of which is the reduction in lenders' costs of gathering information about the characteristics and behaviour of borrowers. Asymmetric information is an especially acute problem in financial markets, leading to difficulties of moral hazard and adverse selection that distort allocations, such as the diversion of resources towards the informal (less efficient) sectors of the economy. As financial markets develop and the problem becomes less severe, better terms and conditions of financial contracts can be offered. Capasso and Jappelli (2013) (CJ2013 later on) formalise this argument by exploiting the theory of optimal contract design in a principal-agent setting. The general idea is that informational asymmetries between borrowers and lenders cause the latter to design contracts in such a way that the former face a probability of being credit rationed. A borrower can reduce this probability by publicly declaring a larger amount of his wealth, but in doing so he faces a larger tax liability. The aim is to show how the marginal benefit of this choice is positively affected by the degree of financial development.

More specifically, CJ2013 develop a model in which agents are endowed with an initial amount of wealth which is liable to taxation. By declaring only part of this wealth and concealing the remainder, agents are able to reduce their tax liability. On the other hand, wealth serves as collateral against loans that are needed to engage in some lucrative, but risky, investment project. The returns on this project differ across agents because of differences in skills and abilities. 
Financial intermediaries set the terms and conditions of loan contracts based on the amount of wealth declared, their uncertainty about project outcomes and their limited information about an agent's type. These terms and conditions will be characterised by an interest rate on loans and a probability that a loan will be granted. Given the financial contract structure, both of these features will depend on the amount of collateral that agents put up: specifically, agents will face a lower loan repayment, and a higher prospect of credit, the more of their wealth they declare. Given this, agents choose their optimal level of tax evasion so as to maximise their expected utility. Moreover this choice will depend on the degree of financial development, as measured by the costs of financial intermediation: specifically, that tax evasion falls as the costs of intermediation falls because of the cheaper credit offered by intermediaries which makes it less profitable for agents to hide their income. The result is that financial development is conducive to a smaller size of underground economy.

CJ2013 also provide an empirical test of the hypothesis that financial development cause the size of the underground economy to decrease. By using the Bank of Italy's Survey of Households Income and Wealth (SHIW), the paper builds an index of the underground economy based on individual-level data. The index measures the level of work irregularity among Italian workers from 1989 to 2006, and ranges from 0 (activities are only in the the individual works in the formal sector) to 1 (activity is completely hidden). This index is regressed on an indicator of financial development and other individual and regional variables. The results show that the underground economy is strongly negatively correlated with financial development and that more competitive and innovative sectors display a lower levels of underground activity.

More recently the literature has attempted to investigate the inverse causal relationship between the underground economy and the working of the financial market (Capasso et al. 2015) (CMS2015 later on). The notion is that the level of underground economy interacts with some aspects of the bank-lending process, such as monitoring and bank-firm relationships, and it can affect the banking sector.

In granting credit, banks apply different lending technologies. The choice of the lending procedure is determined by various factors such as the primary information source, screening and underwriting policies and procedures, the loan contract structure, and monitoring strategies and mechanisms (Berger and Udell, 2002). The idea is that lending technologies can also be influenced by the level of shadow economy according to the following mechanism.

Entrepreneurs going underground hide revenues and fabricate their financial accounts primarily to escape the tax burden and social security contributions. Yet by doing so, they become more opaque to potential lenders, and their ability to signal income returns and endowments decreases. The result of this action is an increase in the probability of being credit rationed.

Indeed, financial accounts and tax statements are among the primary sources of information needed by banks to grant credit. These types of documentation represent a relatively inexpensive way to collect information on borrowers (hard information) and represent the bulk of what the literature labels as "transaction lending technology" (Berger and Udell, 1995). On the wide spectrum of lending technologies ${ }^{3}$, the latter could be considered to be more efficient since they

\footnotetext{
3 Berger and Udell (2006) argue that there are a number of distinct transaction technologies used by financial institutions, including financial statement lending, small business credit scoring, asset-based lending, factoring, fixed-asset lending, and leasing.
} 
allow standardized procedures by decreasing the intensity of monitoring and screening and, in turn, lending costs. However, transaction lending technologies may be optimally implemented only when the bank primarily faces transparent borrowers. On the contrary, if the bank operates in a market plagued by informal firms that can only provide poor quality hard information, standardized lending procedures might decrease the banks' revenue to the extent that they cannot be profitable. In fact, when facing a large number of underground opaque firms and more intense informational problems, banks may find it optimal to mitigate these informational frictions through more intense monitoring. Specifically, more intense monitoring allows bank to access private information (namely soft information) and, consequently, to measure firm's real business and profitability.

From the borrowers' perspectives, a switch from standardized procedures to a more intense monitoring technology is not necessarily damaging. In fact, if on the one hand, this shift may lead to an increase in the cost of credit - higher loan interest rates or additional collateral requirements -on the other hand, it entails a lower probability of being credit rationed. From a lender's perspective, deep monitoring procedures are certainly more costly, but they deliver more accurate information on borrowers. Hence, if the bank operates in an environment in which it is difficult to gather information because of the widespread level of informality, a banking model characterized by more stringent and in-depth monitoring can offer rewards with respect to other apparently less costly banking models. Hence, one can argue that there is a positive relationship between the level of the underground economy and the intensity of bank monitoring.

CMS2015 present both a theoretical model and an empirical test. The model attempts to show how the level of the underground economy can affect bank's optimal decision regarding the level of monitoring to apply. In a simple theoretical framework in which banks optimally choose the lending technology in the presence of informal firms. Banks can either issue credit by employing low cost monitoring procedures (transaction lending technology) or by employing more in-depth investigations into borrowers' creditworthiness (relationship lending technology). Although the former technology is less costly, it is not optimal for use when a bank faces a large number of underground firms. Indeed, as the number of underground firms increases, the level of credit constrained firms increases as well, unless banks compensate for the opacity of informal borrowers through more intense monitoring - for example, by collecting more costly soft information. In other words, to maximize profits, banks trade off the increase in the cost of monitoring with an increase in the volume of credit issued. Therefore, the model predicts that given each technology's monitoring costs, the banks will more intensively use relationship lending instead of transaction lending as the number of informal firms grow.

By using data on a large Italian banking group, CMS2015 test model's predictions by means of a quantile regression, and the findings appear to confirm those predictions. In particular, a set of interactions between the shadow economy and the monitoring indicators show that high levels of informality are associated with a more intense use of bank monitoring. 


\section{References}

Antunes, A. R. \& Cavalcanti, T. V. (2007). "Start up costs, limited enforcement and the hidden economy", European Economic Review, 51, pp. 203-224.

Berger, A. \& Udell, G. (2002). "Small Business Credit Availability and Relationship Lending: The Importance of Bank Organizational Structure," Economic Journal, Royal Economic Society, vol. 112 (477), F32-F53

Berger, A. \& Udell, G. F. (1995). "Relationship lending and lines of credit in small firm finance", Journal of Business, 68, pp. 351-381.

Capasso, S., Monferrà, S. \& Sampagnaro, G. (2015). "The Shadow Economy and Banks' Lending Technology", CSEF Working Papers, n. 422.

Capasso, S. \& Jappelli, T. (2013). "Financial Development and the Underground Economy", Journal of Development Economics, 111, pp. 167-178 (con T. Jappelli).

Choi, J. \& Thum, M. (2004). Corruption and the shadow economy, International Economic Review, 12/4, pp. 308-342.

Dabla-Norris, E. \& Feltenstein, A. (2005). "The underground economy and its macroeconomic consequences", Journal of Policy Reform, 8, pp. 153-174.

Hindriks, J., Muthoo, A. \& Keen, M. (1999). Corruption, extortion and evasion, Journal of Public Economics, 74, pp. 395-430.

Johnson, S., Kaufmann, D. \& Zoido-Lobatón, P. (1998a). Regulatory discretion and the unofficial economy. The American Economic Review, 88/2, pp. 387-392.

Johnson, S., Kaufmann, D. \& Zoido-Lobatón, P. (1998b). Corruption, public finances and the unofficial economy, Washington, DC, The World Bank discussion paper.

Loayza, N. (1997). "The Economics of the informal Sector", World Bank Woking paper, n. 1727.

Schneider, F. (1997). The shadow economies of Western Europe, Journal of the Institute of Economic Affairs, 17/3, pp. 42-48.

Schneider, F. (1998). Further empirical results of the size of the shadow economy of 17 OECDcountries over time, Paper to be presented at the 54. Congress of the IIPF Cordowa, Argentina and discussion paper, Department of Economics, University of Linz, Linz, Austria.

Schneider, F. (1994). Can the shadow economy be reduced through major tax reforms? An empirical investigation for Austria, Supplement to Public Finance/ Finances Publiques, 49, pp. 137-152.

Schneider, F. (2007). 'Shadow economies and corruption all over the world. What do we really know?', Johannes Kepler University of Linz, Department of Economics, Working Paper No. 617.

Schneider, F. \& Enste, D. (2000). "Shadow economies: size, causes and consequences", Journal of Economic Literature, 38, pp. 77-114. 
Schneider, F. \& Enste, D. (2002). The Shadow Economy: Theoretical Approaches, Empirical Studies, and Political Implications, Cambridge (UK): Cambridge University Press.

Straub, S. (2005). "Informal sector: the credit market channel", Journal of Development Economics, 78, pp. 299-321. 